\title{
POLÍTICAS DE REINSERÇÃO SOCIAL DE CONDENADOS EM MINAS GERAIS: UM ESTUDO DE CASO / SOCIAL POLICIES REINSERTION CONDEMNED IN MINAS GERAIS: A CASE STUDY
}

\author{
Luiz Eduardo Motta ${ }^{1}$ \\ Ludmila Ribeiro $^{2}$ \\ Andressa Moura ${ }^{3}$
}

\section{RESUMO}

$\mathrm{O}$ artigo tem como objetivo analisar a eficiência de uma política penitenciária. Para tanto, foi realizado um estudo (quantitativo e qualitativo) na maior penitenciária de Minas Gerais, o qual contrastou o perfil dos detentos com as políticas públicas de reinserção social, executadas pela administração penitenciária. Os dados indicaram que apesar de as políticas propostas pela administração penitenciária se coadunarem com o perfil e com os interesses dos encarcerados essas ainda são incapazes de produzir os efeitos por ela pretendidos.

Palavras - chaves: crime, ordem social, Estado, prisão, punição.

\begin{abstract}
This article analyzes the efficiency of a penitentiary public policy. For this, the authors have made a quantitative and qualitative research about the characteristic of the prisoners and the reeducate's polices implement inside the largest penitentiary of Minas Gerais State. The data indicates that despite the actions planed and executed by the public administration are in the same way of the prisoner's characteristics, the politics' propose remains without reach, untouchable.
\end{abstract}

Key - words: crime, social order, state, prision, punishement.

\section{1 - Introdução}

$\mathrm{O}$ artigo tem como objetivo analisar a eficiência da política prisional do estado de Minas Gerais, por meio do contraste do perfil dos indivíduos condenados à pena privativa de liberdade em consonância com as políticas públicas de reinserção social propostas pela administração pública estadual. A pesquisa consistiu em uma análise quantitativa e

\footnotetext{
${ }^{1}$ Doutor em sociologia pelo IUPERJ, mestre em sociologia pelo IFCS/UFRJ e bacharel em Ciências Sociais pelo IFCS/UFRJ; professor da Faculdade de Direito da UERJ - luizpmotta@ig.com.br

${ }^{2}$ Doutoranda em sociologia pelo IUPERJ, mestre em Administração Pública pela FJP e bacharel em Direito pela UFMG ; professora e pesquisadora da Fundação João Pinheiro- $\underline{\text { |ribeiro@iuperi.br }}{ }^{3}$ Bacharel em direito pela UFMG e bacharel em administração pública pela FJP.
} 
qualitativa, através de estudo de caso, na maior penitenciária do estado, a "Penitenciária José Maria de Alkimim".

No intuito de alcançar tal propósito, além da revisão da bibliografia pertinente, foi realizado um levantamento do perfil dos sentenciados da RMBH junto ao INFOPEN, e o cotejo deste ao perfil da população não-criminosa pelos dados coletados no Atlas de Desenvolvimento Humano no Brasil de 2000 e na Pesquisa de Emprego e Desemprego da Fundação João Pinheiro de 2003, com as seguintes características: idade, tipos de ocorrências criminosas, escolaridade e ocupação. Depois, foram realizadas entrevistas semi-estruturadas com 30 sentenciados $^{3}$ da Penitenciária José Maria Alkimin em Ribeirão das Neves/MG para apreender, em que medida, o projeto atende ou não às necessidades dos egressos, e quais as falhas dos estabelecimentos penitenciários segundo os sentenciados. Após a coleta de dados, esses foram agrupados em categorias de análise para delinear o perfil do condenado e a política de reinserção social em suas diferentes dimensões, quais sejam: a) assistência psicossocial, b) profissional e c) educacional aos beneficiários e familiares.

Por fim, concluiu-se que estes parâmetros se coadunam ao perfil e interesses dos encarcerados, posto que os sentenciados são em sua maioria jovens, pouco escolarizados e, malgrado terem exercido algum tipo de atividade laboral antes de adentrar o estabelecimento penitenciário, estas configuravam atividades mal remuneradas, desqualificadas e instáveis, deficiências estas que não são sanadas ou ao menos minimizadas durante o cumprimento da pena.

2 - O crime e a sua função na sociedade contemporânea.

Resta cediço, no estudo da sociologia criminal, que esta não se limita a formular em termos sociológicos uma indagação de nível individual: porque se cometem crimes? Mas questiona, a propósito e em relação com o crime, a própria ordem social. Desta forma, o crime deixa de ser visto como uma patologia (doença do indivíduo), mas como um fenômeno normal, passível de existir em qualquer sociedade (Cerqueira e Lobão, 2003).

\footnotetext{
${ }^{3}$ Foram entrevistados trinta presos, uma vez que esse é o número resultante do cálculo de uma amostra aleatória de toda a população prisional da RMBH (150 presos).
} 
Émile Durkheim (1999) foi quem primeiro sistematizou uma interpretação sociológica para o fenômeno da criminalidade, aduzindo que os comportamentos desviantes são produtos da própria coletividade, sendo, por isso, normais em qualquer sociedade. Ora, se o crime não é considerado uma "doença social", mas um fenômeno normal da sociedade, a pena não tem o fito de curá-lo, mas sim, de manter a normalidade social punindo o ofensor e, pro conseguinte, reforçando os valores e sentimentos coletivos por ele ofendidos.

Assim, o ato de punir aquele que adotou um comportamento desviante significa a reafirmação dos valores socialmente aceitos, garantindo a coesão social. Para que esta atividade seja eficiente, ou seja, para que o indivíduo seja punido apenas uma vez e não venha a cometer novamente a conduta delituosa, é necessário que aquele que o pune, identifique as falhas cometidas pelos sistemas de controle social (família, escola, etc) na primeira socialização do indivíduo, para que essas possam ser corrigidas evitando-se, com isso, que o indivíduo cometa nova conduta delituosa.

Para usar uma terminação Durkheiniana, quando as sociedades eram caracterizadas por uma solidariedade mecânica, esta atividade era realizada prontamente pelos próprios membros do clã ou da família e, em algumas situações, pelo próprio indivíduo que, sabedouro do caráter errôneo de sua conduta, se afastava da sociedade ou retirava a sua vida, tal como retratado por Mallinovisk (1979). Com o aumento da complexidade social, principalmente, pelo advento da vida em grandes cidades, esta atividade de identificação da conduta desviante, punição do errante e restauração da ordem para a ser exercita pelo poder estatal, corporificado em seu sistema de justiça criminal. Assim, na modernidade, o Estado assume o papel centralizador na formulação e execução de políticas públicas de prevenção e repressão do crime, controle e punição dos criminosos, as quais devem permitir aos cidadãos uma vida tranqüila, de acordo com os valores legais colocados pela justiça estatal. Isso porque, se o crime é resultante de deficiências de controle social, cabe ao Estado auxiliar na sua prevenção.

No intuito de compreender não como a ordem se mantém apesar da ocorrência de um delito, mas, quais os fatores que podem levar um indivíduo a cometer um crime, Robert K. Merton (1968) perquiriu quais as características da sociedade que exercem uma determinada pressão em certas pessoas, induzindo-as a adotarem comportamentos desviantes. Segundo o sociólogo, as sociedades modernas vivem situações de disjunção entre as metas de 
sucesso econômico e os meios legítimos para atingi-las. Segundo o autor, o problema da criminalidade emerge a partir da disseminação da idéia de sucesso a qualquer custo, a qual não se faz acompanhada do oferecimento de oportunidades lícitas para tanto. Tal disfunção provoca a anomia, dando ensejo, por conseguinte, ao comportamento desviante. Desta elaboração teórica infere-se que a estrutura das oportunidades reais que condiciona a possibilidade dos membros sociais se orientarem para os objetivos culturais segundo as normas institucionalizadas, pode levar a uma afinidade entre pobreza e criminalidade: grupos sociais privados de condições sócio-econômicas estão potencialmente mais propensos às pressões para adesão a comportamentos desviantes, tendo em vista a penetração de ideologias igualitárias de sucesso (padrão específico de vestuário, automóveis de determinado modelo, etc.), a serem auferidas por meio do dinheiro.

A partir dessas duas teorias, é possível afirmar que o criminoso é um produto da própria sociedade, posto que as motivações para a adoção do comportamento desviante estão nas rotinas que determinam a sua inserção em uma dada coletividade. Ou seja, é pelo incentivo ao alcance de bens e padrões de vida que não estão disponíveis a determinados segmentos da população que o crime pode ocorrer e uma vez que o comportamento desviante se instaura, a pena (díade do crime) reforça a moral coletiva através da punição aplicada proporcionalmente à intensidade da moral ofendida. Como modernidade pressupõe complexidade da vida social, esta punição não pode ser instituída pelo indivíduo ou por sua família, mas apenas, por uma entidade social que corporifique a vontade da coletividade. Assim, incumbe ao Estado, através do Poder Judiciário, estabelecer a pena na justa medida do ilícito cometido, determinando a modalidade de punição e, sendo essa a privativa de liberdade, a qualidade do regime e a modalidade de seu início, bem como garantir os direitos e deveres dos presos. E ao Estado incumbe ainda, por meio do Poder Executivo, proceder à execução da sentença condenatória, em consonância com os preceitos de ressocialização, de forma a conferir ao criminoso um tratamento penitenciário adequado, possível de reinseri-lo à sociedade, evitando, dessa forma, a reincidência criminal.

3 - A função dos estabelecimentos penitenciários e sua atual conjuntura

Consoante Foucault (2000), a prisão, como uma instituição disciplinar, deve transformar o detento em um "corpo dócil e útil à sociedade", isto é, aquele que pode ser 
submetido, controlado, transformado e aperfeiçoado, de tal forma que o criminoso seja transformado em um cidadão, cuja conduta não mais transgrida as normas sociais. Assim, o objetivo da prisão é que, ao final da pena, o condenado seja despojado de suas concepções sociais anteriores (criminosas) e se torne um indivíduo, que internaliza uma personalidade em consonância com a consciência coletiva.

Esse desiderato é alcançado a partir da vivência da rotina penitenciária, a qual para ser efetiva e eficaz quanto aos seus fins, deve pautar-se, segundo análise de Foucault (2000), pelos seguintes princípios: a) correção: a detenção penal deve ter por função modificar o comportamento do indivíduo, através da educação, tendo como parâmetro os valores que compõem a consciência comum, isto é, o encarcerado sofre um processo de ressocialização social, de internalização da cultura e dos valores postos pela sociedade como "normais"; b) classificação: os encarcerados devem ser separados consoante a gravidade do ilícito cometido, bem como sua idade, disposições, as técnicas de recuperação que lhes serão aplicadas segundo as fases de sua transformação; c) modulação das penas: as punições devem ser aplicadas consoante a personalidade dos encarcerados, acompanhando sua evolução e retrocesso; d) trabalho como obrigação e como direito: o labor deve ser aplicado como algo que atenue a pena e não como uma forma de punição em si mesma, permitindo ao preso o aprendizado de um ofício e a geração de renda; f) educação penitenciária: objetiva o melhoramento das capacidades técnicas dos detentos e, por isso, aumenta significativamente as chances do egresso conseguir emprego no mercado formal de trabalho; g) controle técnico da detenção: o regime de cumprimento de pena deve ser supervisionado por pessoa capacitada técnica e moralmente à boa formação do indivíduo, evitando a ocorrência de condutas, gestos, palavras, quaisquer atos que comprometam a transformação do indivíduo; h) instituições anexas: o encarceramento deve ser acompanhado de medidas de controle e de assistência até a readaptação definitiva do detento. A partir da materialização desses princípios, os estabelecimentos penitenciários passam a servir a uma dupla função: proteger a comunidade dos criminosos e seus respectivos delitos, bem como manter estes segregados da realidade a fim de que possam reaprender as normas que pautam a convivência coletiva.

Para o alcance dos referidos propósitos, Goffman (1999) entende que a unidade carcerária se conforma como instituição total, entendida como local de residência e trabalho onde indivíduos, na mesma condição e separados da sociedade, levam uma vida fechada e 
formalmente administrada. Daí porque as unidades penais, na perspectiva desse autor, devem reproduzir as condições de residência e trabalho da sociedade, para que o indivíduo possa, durante certo tempo determinado, sobreviver alheio a sociedade em geral, mas, dentro de uma reprodução perfeita desta, algo passível de ser alcançado por meio dos seguintes procedimentos: a) barreiras físicas: são medidas tomadas a fim de segregar o indivíduodetento da sociedade civil, tais como muralhas, cadeados, visitas restritas, dentre outros; b). sujeição ao exame criminológico: exame realizado por uma série de especialistas (psicólogos, advogados, assistentes sociais, médicos, criminólogos etc.) a fim de se elaborar um relatório contendo o perfil daquele detento a fim de que se possa validar constantemente sua evolução ou recaída durante a execução penal, c) processos de admissão: momento em que o detento relata sua história e é identificado pela instituição penal como um interno: corresponde aos processos de pesar, medir, tomar banho, vestir o uniforme, preencher a ficha sobre a estória de vida pessoal, dentre outros rituais que marcam o rompimento com a vida livre e o início da vida formalmente administrada; d) impossibilidade de resistência ao processo de substituição: materializada no recolhimento de todos os utensílios pessoais do detento e entrega a este dos bens institucionais, a fim de endossar sua relação de identificação com o estabelecimento penitenciário; e) execução obrigatória das atividades: aplica-se ao detento as atividades compulsórias, ainda que estranhas a ele, como forma de ajudar a transformação do indivíduo. Apenas a internalização de todos esses procedimentos no âmbito do estabelecimento penitenciário pode fazer com este se conforme em um macrocosmo da vida social e, por conseguinte, fazer com que o preso se transforme em um indivíduo em sociedade, mas, que por um determinado lapso de tempo tem a sua vida administrada não apenas por sua vontade e sim pelas normas de funcionários que impõem a moral coletiva com maior exegese.

Todavia, o sistema penitenciário brasileiro é dotado de diversos problemas que inibem uma execução penal nos moldes preconizados pelos estudos de Goffman e Foucault. Resta cediço que as condições de cumprimento de penas no Brasil são cruéis, degradantes e desumanas e muito distante da consubstanciação de um microcosmo social. Os níveis de superpopulação são dramáticos e as condições sanitárias, vexatórias. A violência entre os presos é comum, e os espancamentos de presos por policiais rotineiros, como se fosse de praxe. As assistências consagradas pela Lei de Execução Penal são deficitárias. Sabe-se que 
as assistências médicas e jurídicas são ínfimas e deficientes, e até mesmo o trabalho, dever do Estado, é quase inexistente. Vestuário e artigos básicos de higiene, como sabonete, creme dental e papel higiênico são raramente distribuídos. Como se não bastasse, o índice de fugas é elevadíssimo, ademais do fácil trânsito de drogas dentro do estabelecimento penitenciário, armas e telefones celulares apontarem o alto grau de corrupção (Human

Rights Watch, 1998)

Nesses termos, é possível classificar os problemas carcerários brasileiros em dois grandes grupos: o primeiro são os problemas decorrentes da má gestão da coisa pública, falta de interesse político, inabilidade administrativa e técnica. São exemplos desse grupo: presídios sem a infra-estrutura mínima necessária, material e humana, para o cumprimento de pena, faltam condições materiais e humanas para o incremento dos regimes progressivos de cumprimento de pena, consoante dispõe o texto legal, superpopulação carcerária, etc. O segundo grupo são os problemas inerentes à própria natureza da pena privativa de liberdade e os inerentes à própria natureza do cárcere. São eles: o isolamento da família, a segregação em relação à sociedade, a convivência forçada em meio delinqüente, o sistema de poder controlando todos os atos do indivíduo, relações contraditórias e ambivalentes entre o pessoal penitenciário e os presos (quem oferece apoio é quem os reprime e os pune). A grande diferença do segundo grupo em relação ao primeiro é que seus problemas são praticamente inevitáveis. Em sendo dessa forma, o desafio atual das políticas penitenciárias consiste em, simultaneamente, buscar encaminhamento de soluções aos problemas do primeiro e, por conseguinte, mitigar dos problemas do segundo grupo.

\section{4 - Panorama geral do sistema penitenciário de Minas Gerais}

Com cerca de 240.203 detentos, distribuídos em 179.489 vagas penitenciárias, o Brasil administra um dos dez maiores sistemas penitenciários do mundo, uma vez que apenas onze países possuem mais de 100.000 pessoas encarceradas (MINISTÉRIO DA JUSTIÇA, 2004). No entanto, o índice de encarceramento brasileiro - isto é, a razão presopopulação - é relativamente moderada, já que para cada grupo de 100.000 habitantes, 181 pessoas encontram-se encarceradas. Essa média é superior a da Colômbia (110 presos para cada 100.000 hab.), México (108) e Venezuela (113 presos para cada 100.000 hab.) e inferior a do 
Chile (173 presos para cada 100.000 hab.) e Estados Unidos da América - EUA (645 presos para cada 100.000 hab.), conforme demonstram os dados do FBI (2004).

O sistema penitenciário brasileiro, no entanto, revela uma peculiaridade em relação aos existentes em outros países do mundo, pois, segundo a Human Rights Watch (1998), "em todos os sentidos, o sistema penal brasileiro é enorme. Diferente dos outros países, o Brasil não possui uma autoridade prisional centralizadora. Ao invés de um sistema nacional, cada estado administra seu complexo de penitenciárias, cadeias e delegacias”.

Por outro lado, o grande contingente de presos brasileiros encontra-se diversamente distribuído no território nacional. São Paulo, o estado mais populoso do Brasil, tem, de longe, a maior população carcerária e a maior incidência relativa de encarceramento. Outros estados com significativas populações carcerárias são os estados do Rio de Janeiro, Minas Gerais, Rio Grande do Sul, Paraná e Bahia, conforme demonstrado no Quadro 1:

Quadro 1 - Síntese do atual sistema carcerário brasileiro - número de presos, taxa de encarceramento, número de vagas e déficit de vagas prisionais

\begin{tabular}{|c|c|c|c|c|c|}
\hline Estado & População & $\begin{array}{l}\text { População } \\
\text { Prisional } \\
\end{array}$ & $\begin{array}{l}\text { Presos por } 100.00 \\
\text { habitantes }\end{array}$ & Vagas existentes & Déficit de vagas \\
\hline Brasil & 169.799 .170 & 308.304 & 181,57 & 179.489 & 128.815 \\
\hline São Paulo & 37.032 .403 & 123.932 & 334,66 & 71.515 & 52.417 \\
\hline Minas Gerais & 17.891 .494 & 23.156 & 129,42 & 5.544 & 17.612 \\
\hline Rio Grande do Sul & 10.187 .798 & 22.557 & 221,41 & 15.665 & 6.892 \\
\hline Rio de Janeiro & 14.391.282 & 18.562 & 128,98 & 17.721 & 841 \\
\hline Paraná & 9.563 .458 & 13.689 & 143,14 & 7.075 & 6.614 \\
\hline Pernambuco & 7.918.344 & 12.488 & 157,71 & 8.600 & 3.888 \\
\hline Ceará & 7.430 .661 & 11.939 & 160,67 & 5.903 & 6.036 \\
\hline Mato Grosso & 2.504 .353 & 7.674 & 306,43 & 5.430 & 2.244 \\
\hline Goiás & 5.003 .228 & 7.576 & 151,42 & 2.351 & 5.225 \\
\hline Santa Catarina & 5.356 .360 & 7.139 & 133,28 & 6.013 & 1.126 \\
\hline Distrito Federal & 2.051 .146 & 6.947 & 338,69 & 4.191 & 2.756 \\
\hline Espírito Santo & 3.097 .232 & 6.353 & 205,12 & 1.783 & 4.570 \\
\hline Mato Grosso do Sul & 2.078 .001 & 6.338 & 305,00 & 2.376 & 3.962 \\
\hline Pará & 6.192 .307 & 5.661 & 91,42 & 3.446 & 2.215 \\
\hline Paraíba & 3.443 .825 & 5.414 & 157,21 & 3.005 & 2.409 \\
\hline Bahia & 13.070 .250 & 5.317 & 40,68 & 4.364 & 953 \\
\hline Maranhão & 5.651 .475 & 4.567 & 80,81 & 1.176 & 3.391 \\
\hline Rondônia & 1.379 .787 & 3.738 & 270,91 & 1.517 & 2.221 \\
\hline
\end{tabular}




\begin{tabular}{|c|c|c|c|c|c|}
\hline Sergipe & 1.784 .475 & 2.794 & 156,57 & 1.219 & 1.575 \\
\hline Amazonas & 2.812 .557 & 2.122 & 75,45 & 1.841 & 281 \\
\hline Piauí & 2.843 .278 & 1.964 & 69,08 & 1.705 & 259 \\
\hline Acre & 557.526 & 1.947 & 349,22 & 1.113 & 834 \\
\hline Alagoas & 2.822 .621 & 1.821 & 64,51 & 1.427 & 394 \\
\hline Rio Grande do Norte & 2.776 .782 & 1.796 & 64,68 & 2.203 & -407 \\
\hline Tocantins & 1.157 .098 & 1.309 & 113,13 & 1.166 & 143 \\
\hline Amapá & 477.032 & 931 & 195,17 & 716 & 215 \\
\hline Roraima & 324.397 & 573 & 176,64 & 424 & 149 \\
\hline
\end{tabular}

Fonte: Ministério de Justiça / Departamento Penitenciário Nacional - Abril de 2004.

O sistema prisional brasileiro, atualmente, compõe-se dos estabelecimentos penitenciários, locais onde são matriculados os indivíduos condenados de maneira definitiva e dos distritos policiais onde se encontram os provisoriamente detidos. Segundo Lemgruber (2000), apesar dos estabelecimentos penais brasileiros espalharem-se por todo o país, estes se concentram nos arredores das zonas urbanas e regiões mais populosas, bem como nos estados que concentram as maiores populações carcerárias. Entretanto, os estabelecimentos penitenciários são incapazes de absorver o atual contingente de presos já condenados. Com isso, muitos destes presos continuam a ser lotados nos distritos policiais, o que agride não apenas as determinações legais, como também os propósitos da pena privativa de liberdade, dada a impossibilidade de execução de uma política pública de ressocialização e reinserção social do criminoso em locais onde nem mesmo a integridade física do indivíduo pode ser garantida (HUMAN RIGHTS WATCH, 1998).

Assim, conforme verificado no Quadro 1, São Paulo possui não apenas a maior população carcerária do país como o maior déficit de vagas prisionais em termos absolutos (quase a metade do total do país), sendo seguido por Minas Gerais, Paraná, e Rio Grande do Sul. Nesse sentido, é possível concluir que a questão prisional é, sem dúvida, um problema público de toda a federação brasileira, conforme demonstra o Quadro 2:

Quadro 2: Participação de São Paulo, Rio Grande do Sul, Rio de Janeiro, Paraná e Minas Gerais no Sistema Penitenciário Nacional - 2004

\begin{tabular}{|c|c|c|c|c|c|c|}
\hline & \multicolumn{2}{|c|}{ Vagas Disponíveis } & \multicolumn{2}{|c|}{ População Carcerária } & \multicolumn{2}{|c|}{ Déficit Total de Vagas } \\
\hline & Total & $\%$ & Total & $\%$ & Total & $\%$ \\
\hline Brasil & 179.489 & 100 & 308.304 & 100 & 128.815 & 100 \\
\hline São Paulo & 71.515 & 39,84 & 123.932 & 40,19 & 52.417 & 40,69 \\
\hline
\end{tabular}




\begin{tabular}{|l|r|r|r|r|r|r|}
\hline Minas Gerais & 5.544 & 3,08 & 23.156 & 7,51 & 17.612 & 13,67 \\
\hline Rio Grande do Sul & 15.665 & 8,72 & 22.557 & 7,31 & 6.892 & 5,35 \\
\hline Rio de Janeiro & 17.721 & 9,87 & 18.562 & 6,02 & 841 & 0,65 \\
\hline Paraná & 7.075 & 3,94 & 13.689 & 4,44 & 6.614 & 5,13 \\
\hline
\end{tabular}

Fonte: Ministério de Justiça / Departamento Penitenciário Nacional - Abril de 2004

Nesse sentido, conforme o quadro acima permite concluir, o estado de Minas Gerais, sozinho, acumula $13,67 \%$ do déficit total de vagas do sistema penitenciário brasileiro, mesmo possuindo apenas 7,51\% do total da população carcerária. Comparativamente, o Rio Grande do Sul possui uma população carcerária, em termos numéricos, bem semelhante ao estado de Minas Gerais, ou seja, 7,32\% do total brasileiro. Contudo, seu déficit de vagas é $25 \%$, ou seja, menor do que o estado em análise, o que demonstra a gravidade do problema mineiro. Situação semelhante à de Minas Gerais é vivenciada pelo estado de São Paulo, o qual possui 39,84\% dos presos nacionais e acumula um déficit de 40,69\% das vagas penitenciárias nacionais. Cabe ressaltar que esse estado possui um grande déficit de vagas em razão do tamanho de seu contigente carcerário, o que não significa dizer que a maioria de seus presos encontra-se encarcerado em delegacias, ao contrário do disposto pela LEP (BRASIL, 2003)

É importante destacar ainda a situação favorável existente no Rio de Janeiro, estado que apesar de se constituir enquanto o quarto maior sistema penitenciário nacional, encarcerando 9,87\% dos presos existentes no Brasil, praticamente, não possui déficit de vagas penitenciárias, o que significa dizer que todos os criminosos desse estado encontramse matriculados em unidades aptas a desenvolverem políticas públicas de ressocialização do sentenciado, algo muito distinto do observado em estados como Minas Gerais e Paraná, nos quais uma porcentagem considerável de indivíduos delinqüentes encontra-se em cadeias e delegacias, nas quais nem a sua integridade física é assegurada (Quadro 3).

Quadro 3: Déficit de vagas penitenciárias em São Paulo, Minas Gerais, Rio Grande do Sul e Paraná

\begin{tabular}{|l|r|r|r|r|}
\hline & São Paulo & Minas Gerais & Rio Grande do & Paraná \\
\hline & & & \multicolumn{1}{l|}{ Sul } & \\
\hline Total de Presos (sistema penitenciário + polícia civil) & 123.932 & 23.156 & 22.557 & 13.689 \\
\hline Presos sob custódia da polícia civil & 24.906 & 17.718 & 4.136 & 6.200 \\
\hline $\begin{array}{l}\text { Déficit de vagas no sistema penitenciário estadual } \\
(\%)\end{array}$ & 20,10 & 76,52 & 18,34 & 45,29 \\
\hline
\end{tabular}


Os quatro maiores sistemas prisionais do país possuem características muito distintas, no que se refere a distribuição do contingente carcerário entre as distintas agências de controle. Percebe-se que o caso mais problemático é o de Minas Gerais, único estado da federação a possuir um número de presos sob guarda da Polícia Civil bastante superior à aquele matriculado no sistema penitenciário propriamente dito, algo que compromete diretamente a realização dos propósitos de mortificação da personalidade, disciplina e transformação da personalidade do indivíduo, conforme pressupõe a doutrina penitenciária (FOUCAULT, 1987; GOFFFMAN, 1987).

Nesse sentido, conforme demonstram várias pesquisas realizadas na área (LEMGRUBER, 2000; HUMAN RIGHTS WATCH, 1998; PINHEIRO, 1997), os estabelecimentos penais mais superlotados, no Brasil, são geralmente as delegacias de polícia, pois ao invés de serem usadas para detenções de período curto para suspeitos, mantêm detentos por longos períodos de tempo e até mesmo anos. Nos casos mais extremos, como Paraná e Minas Gerais, a polícia tornou-se, na prática, a autoridade prisional, suplementando e, às vezes, quase substituindo o sistema penitenciário convencional.

Essa situação é extremamente perversa para o Sistema de Justiça Criminal como um todo, pois na maioria das vezes impede a detenção de determinados indivíduos perigosos para a sociedade; inviabiliza a correta execução da investigação criminal, dado que os policiais civis acabam tendo que se ocupar da guarda de presos; e compromete, ainda, a execução de políticas públicas de recuperação do criminoso (PAIXÃO, 1995). Tais obstáculos em muito contribuem para a reprodução do círculo vicioso de delinqüência e impunidade, conforme enfatizado por Paixão (1991). Assim, o sistema prisional acaba constituindo-se em um dos maiores problemas no que se refere à gestão da segurança pública no estado de Minas Gerais.

Minas Gerais não se conforma enquanto exceção a esse caso, apesar de nos últimos anos, a Secretaria de Estado de Defesa Social - SEDS- ter investido na abertura de novas vagas no sistema penitenciário, em detrimento do amontoamento de presos nos distritos policiais. Contudo, a inauguração de novos estabelecimentos prisionais ainda não foi capaz de absorver o contingente total de presos sob custódia da Polícia Civil, mas, teve como 
grande mérito, impedir o crescimento da população criminosa encarcerada nas delegacias (GRÁFICO 1).

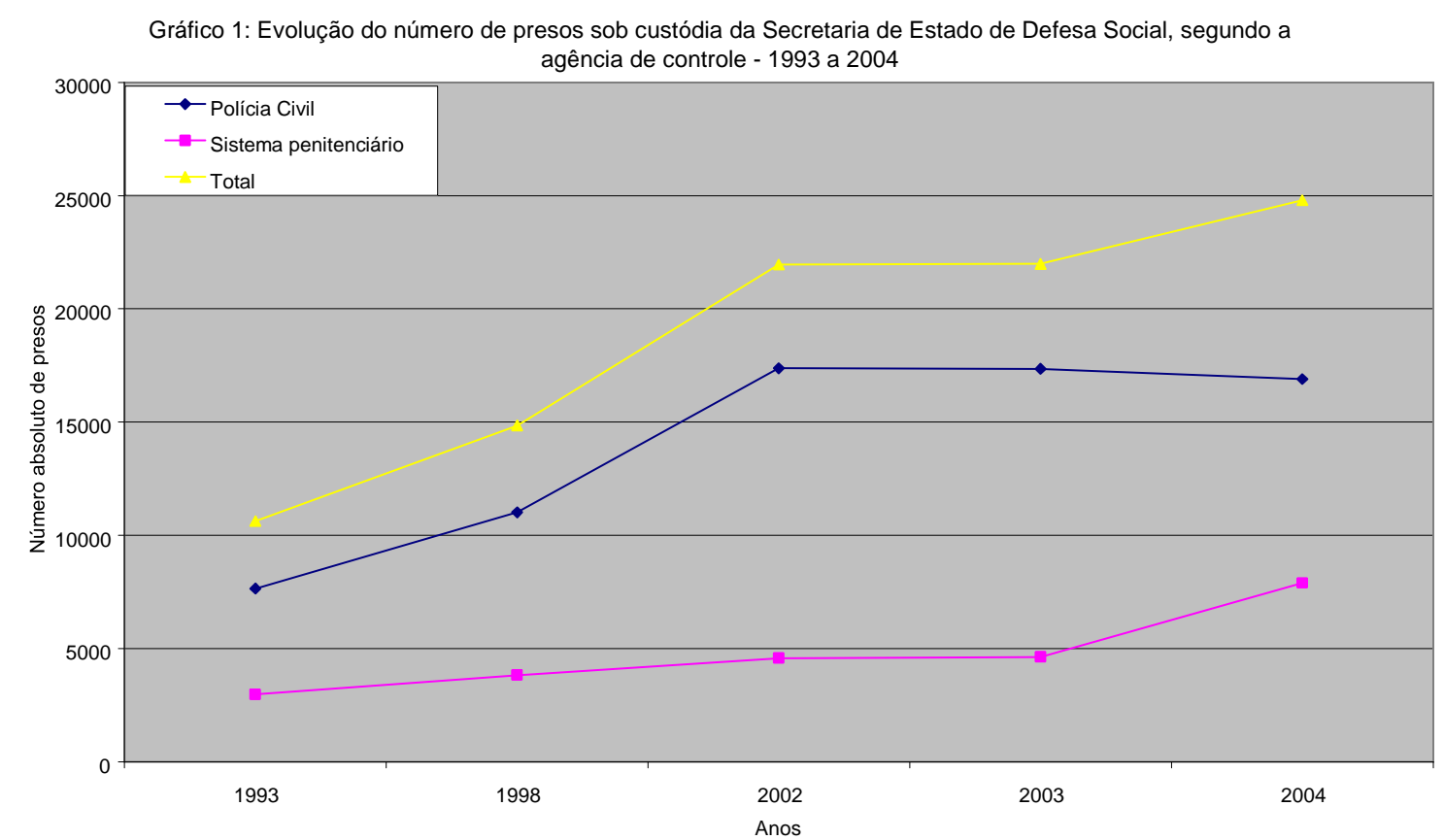

Fonte: Sub-Secretaria de Administração Penitenciária (SUAPE) e Polícia Civil (PC) - Janeiro/05

Entre as possíveis causas dos problemas atualmente vivenciados pelo sistema penitenciário em Minas Gerais, encontra-se a duplicidade de gerenciamento dos encarcerados. O Governo do Estado possui duas instâncias de controle sobre o sistema penitenciário, a Sub-Secretaria de Administração Penitenciária - SUAPE, responsável pelos estabelecimentos penitenciários, e a Polícia Civil - PC, responsável pelas delegacias e cadeias que abrigariam nos termos da lei os presos provisórios, ambas Sub-Secretarias subordinadas à Secretaria de Estado de Defesa Social.

No entanto, essa questão remonta ao início do século XX, pois, de acordo com Paixão (1991, p. 35) "entre as décadas de 30 e 60, não se pode, propriamente, falar num sistema penitenciário mineiro. Havia uma instituição - a Penitenciária Agrícola de Neves - PAN; e o seu peso real e simbólico marcou definitivamente o sistema penitenciário que se implantou a partir dos anos seguintes. Antes a população prisional do estado se distribuía pelas cadeias públicas dos municípios". 
Dessa forma, pode-se afirmar que a atual dualidade de competência para a administração da questão prisional não é um fenômeno recente na história de Minas Gerais, já que antes da criação da PAN (atualmente, Penitenciária José Maria de Alkimin), os condenados, provisórios e em instância definitiva, eram recolhidos nos distritos policiais, sendo que, apenas com a construção do referido estabelecimento, inicia-se o desenvolvimento, em tese, de políticas penitenciárias no estado, tal como pressuposto pela teoria sobre essa temática (FOUCAULT, 1987; GOFFMAN, 1987).

Isso porque, à época de inauguração dessa unidade os processos organizacionais vigentes eram refratários da idéia de mortificação da personalidade, sendo rigidamente controlados, o que, por sua vez, levava à conformação da disciplina enquanto regra visível a todos que visitavam a unidade, permitindo, assim, a emergência de um indivíduo completamente reformado, conforme a sociedade espera (PAIXÃO, 1991). Isso fez com que, apesar de legalmente a guarda dos presos incumbir a Sub-Secretaria de Administração Penitenciária (SUAPE), na atualidade, é primordialmente a PC que vem desempenhando essa função (QUADRO 4). Não obstante essa situação de superlotação dos distritos policiais e acúmulo das funções de investigação de delitos e guarda de presos pela polícia civil, é importante destacar o esforço de expansão do sistema penitenciário, já que, apenas nos dois últimos anos, foram abertas 2820 novas vagas, sendo que destas, 1658 apenas no último ano. Situação essa bastante distinta dos períodos anteriores, uma vez que em 50 anos foram construídas apenas 3559 vagas penitenciárias, algo que denota o descaso com a política prisional nas gestões anteriores e o tamanho do desafio que se apresenta para os gestores públicos atuais.

Quadro 4: Situação Processual dos Presos em Minas Gerais conforme a agência de controle social responsável

\begin{tabular}{|l|l|l|}
\hline Natureza da condição processual & Polícia Civil & Sistema Penitenciário \\
\hline
\end{tabular}




\begin{tabular}{|l|r|r|}
\hline Presos Condenados ao regime fechado & 6.091 & 5.573 \\
\hline Presos Condenados ao regime semi-aberto & 1.900 & 1.971 \\
\hline Presos Condenados ao regime aberto & 998 & 166 \\
\hline Presos Condenados a medida de segurança & 79 & 215 \\
\hline Presos provisórios & 7.831 & 90 \\
\hline Total de presos & 16.899 & 8.015 \\
\hline
\end{tabular}

Fonte: Sub-Secretaria de Administração Penitenciária (SUAPE) e Polícia Civil (PC) - Janeiro/05

Assim, no que se refere ao conjunto de estabelecimentos penais que, atualmente, formam a parte do sistema penitenciário mineiro subordinado a SUAPE, esses são classificados pela Lei de Execução Penal - LEP em penitenciárias, presídios e casas de albergado, que se destinam aos presos condenados, para cumprimento de pena privativa de liberdade, e hospitais de custódia, os quais se ocupam do cumprimento de medidas de segurança, bem como da realização de exame de periculosidade e dependência toxicológica. Essa diversidade de estabelecimentos para a execução penal tem como objetivo propiciar ao condenado o tratamento mais adequado à sua personalidade. Isso porque, pressupõe-se que a partir da homogeneidade no âmbito da unidade penal, os processos de tratamento e os de disciplina podem ser implementados com maior sucesso, permitindo à unidade se conformar, efetivamente, em empresas modificadoras do indivíduo, posto que não existem incongruências no âmbito dessa, já que o estabelecimento deve efetivar um único tipo de tratamento para uma massa homogênea de detentos. Em Minas Gerais, esse processo acontece por meio das seguintes unidades subordinadas à SUAPE:

Quadro 5: Estabelecimentos penitenciários que se encontram sob gerência da Sub-Secretaria de Administração Penitenciária - SUAPE - 2004

\begin{tabular}{|c|c|c|c|c|c|c|c|}
\hline \multirow[t]{2}{*}{ Nome da unidade } & \multirow[t]{2}{*}{ Sigla } & \multirow{2}{*}{$\begin{array}{l}\text { Ano de } \\
\text { Criação }\end{array}$} & \multirow[t]{2}{*}{ Localização } & \multirow{2}{*}{$\begin{array}{c}\text { Regimes que } \\
\text { abriga }\end{array}$} & \multicolumn{3}{|c|}{ Capacidade } \\
\hline & & & & & Fechado & Semi-aberto & Aberto \\
\hline Hospital Psiquiátrico Jorge Vaz & HPJJV & 1927 & Barbacena & Fechado & 215 & & $\mathrm{X}$ \\
\hline $\begin{array}{l}\text { Penitenciária José Maria de } \\
\text { Alkimin }\end{array}$ & PJMA & 1937 & $\begin{array}{l}\text { Ribeirão das } \\
\text { Neves }\end{array}$ & $\begin{array}{l}\text { Fechado e } \\
\text { Semi-aberto }\end{array}$ & 600 & 200 & $X$ \\
\hline \begin{tabular}{|l} 
Complexo Penitenciário \\
Feminino Estevão Pinto \\
\end{tabular} & PIEP & 1948 & \begin{tabular}{|l} 
Belo \\
Horizonte
\end{tabular} & $\begin{array}{l}\text { Fechado e } \\
\text { Semi-aberto }\end{array}$ & 47 & 134 & $X$ \\
\hline $\begin{array}{l}\text { Penitenciária José Edson } \\
\text { Cavalieri }\end{array}$ & PJEG & 1966 & Juiz de Fora & $\begin{array}{l}\text { Fechado e } \\
\text { Semi-aberto }\end{array}$ & 140 & 40 & $x$ \\
\hline Penitenciária Teófilo Otoni & PTO & 1977 & Teófilo Otoni & $\begin{array}{l}\text { Fechado e } \\
\text { Semi-aberto }\end{array}$ & 40 & 160 & $x$ \\
\hline
\end{tabular}




\begin{tabular}{|c|c|c|c|c|c|c|c|}
\hline $\begin{array}{l}\text { Casa de Albergado Presidente } \\
\text { João Pessoa }\end{array}$ & CAPJP & 1978 & \begin{tabular}{|l} 
Belo \\
Horizonte
\end{tabular} & Aberto & $\mathrm{X}$ & $X$ & 64 \\
\hline $\begin{array}{l}\text { Penitenciária José Abranches } \\
\text { Gonçalves }\end{array}$ & PJAG & 1980 & $\begin{array}{l}\text { Ribeirão das } \\
\text { Neves }\end{array}$ & Semi-aberto & $\mathrm{X}$ & 72 & $\mathrm{X}$ \\
\hline $\begin{array}{l}\text { Casa de Albergado José de } \\
\text { Alencar Rogedo }\end{array}$ & CAJAR & 1984 & Juiz de Fora & Aberto & $\mathrm{X}$ & $\mathrm{X}$ & 60 \\
\hline $\begin{array}{l}\text { Hospital de Tôxicomanos Pe. } \\
\text { Wilson Vale Costa }\end{array}$ & $\begin{array}{l}\text { HTPW } \\
\text { VC }\end{array}$ & 1987 & Juiz de Fora & Fechado & 97 & $X$ & $\mathrm{X}$ \\
\hline Penitenciária Nelson Hungria & PNH & 1988 & Contagem & Fechado & 893 & $X$ & $X$ \\
\hline $\begin{array}{l}\text { Penitenciária Agostinho de } \\
\text { Oliveira Júnior }\end{array}$ & PAOJ & 1993 & Unaí & $\begin{array}{l}\text { Fechado e } \\
\text { Semi-aberto }\end{array}$ & 348 & 152 & $\mathrm{X}$ \\
\hline $\begin{array}{l}\text { Penitenciária Dênio M. de } \\
\text { Carvalho }\end{array}$ & PDMC & 1993 & Ipaba & $\begin{array}{l}\text { Fechado e } \\
\text { Semi-aberto }\end{array}$ & 298 & 50 & $\mathrm{X}$ \\
\hline Presídio Sebastião Sátiro & PSS & 1997 & $\begin{array}{l}\text { Patos de } \\
\text { Minas }\end{array}$ & $\begin{array}{l}\text { Fechado, } \\
\text { Semi-aberto e } \\
\text { Aberto }\end{array}$ & 61 & 90 & 14 \\
\hline $\begin{array}{l}\text { Penitenciária Francisco Floriano } \\
\text { de Paula }\end{array}$ & PFFP & 1998 & $\begin{array}{l}\text { Governador } \\
\text { Valadares }\end{array}$ & $\begin{array}{l}\text { Fechado e } \\
\text { Semi-aberto }\end{array}$ & 308 & 163 & $\mathrm{X}$ \\
\hline Presídio Floramar & $\mathrm{PF}$ & 1998 & Divinópolis & Fechado & 187 & $X$ & $\mathrm{X}$ \\
\hline Presídio Professor Jacy de Assis & PPJA & 1998 & Uberlândia & $\begin{array}{l}\text { Fechado, } \\
\text { Semi-aberto e } \\
\text { Aberto }\end{array}$ & 258 & 114 & 28 \\
\hline $\begin{array}{l}\text { Penitenciária Nossa Senhora do } \\
\text { Carmo }\end{array}$ & PNSC & 2002 & $\begin{array}{l}\text { Carmo do } \\
\text { Paranaíba } \\
\end{array}$ & $\begin{array}{l}\text { Fechado e } \\
\text { Semi-aberto }\end{array}$ & 48 & 124 & $\mathrm{X}$ \\
\hline $\begin{array}{l}\text { Centro de Apoio Geral São } \\
\text { Francisco }\end{array}$ & CAGSF & 2003 & $\begin{array}{l}\text { Ribeirão das } \\
\text { Neves }\end{array}$ & Fechado & 76 & $\mathrm{X}$ & $\mathrm{X}$ \\
\hline $\begin{array}{l}\text { Penitenciária Prof. Jason Soares } \\
\text { Albergaria }\end{array}$ & PPJSA & 2003 & $\begin{array}{l}\text { São Joaquim } \\
\text { de Bicas } \\
\end{array}$ & $\begin{array}{l}\text { Fechado e } \\
\text { Semi-aberto }\end{array}$ & 224 & 138 & $\mathrm{X}$ \\
\hline $\begin{array}{l}\text { Penitenciária Prof. João Pimenta } \\
\text { da Veiga }\end{array}$ & PPJPV & 2003 & Uberlândia & $\begin{array}{l}\text { Fechado e } \\
\text { Semi-aberto }\end{array}$ & 224 & 138 & $\mathrm{X}$ \\
\hline $\begin{array}{l}\text { Penitenciária Regional Pio } \\
\text { Canedo }\end{array}$ & PRPC & 2003 & Pará de Minas & $\begin{array}{l}\text { Fechado e } \\
\text { Semi-aberto }\end{array}$ & 224 & 138 & $\mathrm{X}$ \\
\hline $\begin{array}{l}\text { Casa de Detenção Antônio Dutra } \\
\text { Ladeira }\end{array}$ & $\begin{array}{l}\text { CDAD } \\
\mathrm{L}\end{array}$ & 2004 & $\begin{array}{l}\text { Ribeirão das } \\
\text { Neves }\end{array}$ & $\begin{array}{l}\text { Fechado e } \\
\text { Semi-aberto }\end{array}$ & 400 & 400 & $\mathrm{X}$ \\
\hline Penitenciária Francisco Sá & PFS & 2004 & Francisco Sá & $\begin{array}{l}\text { Fechado e } \\
\text { semi-aberto }\end{array}$ & 212 & 120 & $\mathrm{X}$ \\
\hline $\begin{array}{l}\text { Penitenciária Professor } \\
\text { Ariosvaldo de Campos Pires }\end{array}$ & PPACP & 2004 & Juiz de Fora & $\begin{array}{l}\text { Fechado e } \\
\text { Semi-aberto }\end{array}$ & 258 & 138 & $\mathrm{X}$ \\
\hline \multirow[t]{2}{*}{ Presídio Irmão Naves } & PIN & 2004 & Araguari & Fechado e & 114 & 16 & $\mathrm{X}$ \\
\hline & & & & Semi-aberto & & & \\
\hline
\end{tabular}

Fonte: Sub-Secretaria de Administração Penitenciária (SUAPE) e Polícia Civil (PC)

Portanto, a SEDS possui, portanto, vinte e quatro estabelecimentos penitenciários que, somados, disponibilizam 7825 vagas. Assim, dos 24.919 presos existentes em todo o 
Estado de Minas Gerais, apenas 32,17\%, entre homens e mulheres, estão sob responsabilidade da SUAPE. Os demais se encontram recolhidos às cadeias e delegacias sob custódia da Polícia Civil. Finalizadas as considerações sobre a forma como sistema prisional de Minas Gerais encontra-se institucionalizado, passa-se a análise do perfil do detento. É importante destacar que para tanto foram utilizados apenas os dados da SUAPE, uma vez que a Polícia Civil não possui bancos de dados com informações qualitativas sobre os presos sob sua custódia.

5 - O perfil da população criminosa da RMBH: mitos e fatos

É comum na opinião pública a suposição de que a população dos estabelecimentos penais seja constituída por uma categoria social distinta da população em geral. Difunde-se a idéia de que os presos têm características de personalidade ou de inserção social que os diferenciam dos seres humanos ditos "normais". Existe um conhecimento de senso-comum que revela serem os criminosos pessoas de baixa-renda, sem instrução escolar e desempregados; imputando a adoção de comportamentos desviantes ao infortúnio da privação econômica ou por carências de ordem social, familiar e afetiva. Assim, procurouse explicitar essas várias características sócio-biográficas dos criminosos no sentido de procurar vislumbrar, em que medida esses estereótipos se materializam ou não nos detentos das penitenciárias da RMBH. Para tanto, foram analisados os seguintes itens: idade; escolaridade e ocupação do detento antes do encarceramento.

Idade: A idade dos presos da RMBH varia entre 18 e 60 anos (Quadro 6). No entanto, a predominância é de jovens, ou seja, aqueles que possuem idade até 40 anos (86,31\% do total). Isso porque essa é a faixa etária na qual o indivíduo encontra-se economicamente ativo e, conforme analisado por Lemgruber (1995), os índices de criminalidade são maiores entre os jovens em razão da necessidade desses em se inserirem no mercado de trabalho. Além disso, como o delito não deixa de ser uma atividade, é necessário fôlego para desempenhá-la, tal como ocorre com as demais ocupações da vida livre e, por isso, esta atividade tende a ser exercida, preponderantemente, pelos jovens.

Quadro 6 - Idade dos presos sob custódia da Sub-secretaria de Administração Penitenciária 


\begin{tabular}{|c|c|c|c|c|c|c|}
\hline Estabelecimentos da RMBH & 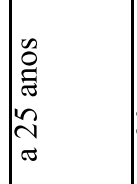 & 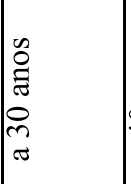 & 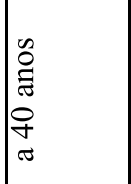 & 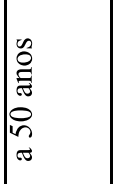 & 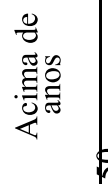 & \\
\hline Casa de Albergado Presidente João Pessoa & 29 & 17 & 1ब्क & 麦 & 4 & 0 \\
\hline Casa de Detenção Antônio Dutra Ladeira & 431 & 228 & 213 & 70 & 30 & 4 \\
\hline Centro de Apoio Geral São Francisco & 1 & 5 & 6 & 6 & 6 & 0 \\
\hline Complexo Penitenciário Feminino Estevão Pinto & 45 & 31 & 44 & 14 & 10 & 0 \\
\hline Penitenciária José Abranches Gonçalves & 60 & 1 & 0 & 0 & 0 & 0 \\
\hline Penitenciária José Maria de Alkimin & 200 & 215 & 244 & 80 & 34 & 3 \\
\hline Penitenciária Nelson Hungria & 222 & 269 & 324 & 107 & 29 & 1 \\
\hline Penitenciária Prof. Jason Soares Albergaria & 124 & 79 & 79 & 36 & 16 & 1 \\
\hline TOTAL RMBH & 1112 & 845 & 924 & 319 & 129 & 9 \\
\hline$\% \mathrm{RMBH}$ & 33,31 & 25,31 & 27,68 & 9,56 & 3,86 & 0,27 \\
\hline$\%$ RMBH em relação ao total de presos & 14,79 & 11,24 & 12,29 & 4,24 & 1,72 & 0,12 \\
\hline
\end{tabular}

Fonte: Secretaria de Estado de Defesa Social - Janeiro de 2005

Ao analisar os dados do IDH (PNUD/FJP, 2003), verifica-se que o número de pessoas entre 18 e 24 anos de idade corresponde à $14,76 \%$ do total de residentes na RMBH, o que revela ter a região uma quantidade significativa de jovens. Para se ter uma idéia, apenas 5,1\% da população total da RMBH tem mais de 65 anos de idade, ao passo que nos estabelecimentos penitenciários da RMBH, os maiores de 50 anos caem para 3,86\% dos encarcerados (Quadro 7).

Quadro 7 - Número de pessoas por faixa de idade, em 2000, na Região Metropolitana de Belo Horizonte (Minas Gerais)

\begin{tabular}{|l|r|r|r|r|r|r|r|}
\hline \multicolumn{1}{|c|}{ Município } & $\begin{array}{c}\text { População } \\
\text { até 1 ano } \\
\text { de idade, } \\
2000\end{array}$ & $\begin{array}{c}\text { População } \\
\text { de 1 a 3 } \\
\text { anos de } \\
\text { idade, } \\
2000\end{array}$ & $\begin{array}{c}\text { População } \\
\text { de 10 a 14 } \\
\text { anos de } \\
\text { idade, } \\
2000\end{array}$ & $\begin{array}{c}\text { População } \\
\text { de 15 a 17 } \\
\text { anos de } \\
\text { idade, } \\
2000\end{array}$ & $\begin{array}{c}\text { População } \\
\text { de 18 22 } \\
\text { anos de } \\
\text { idade, } \\
2000\end{array}$ & $\begin{array}{c}\text { População } \\
\text { de 23 a 24 } \\
\text { anos de } \\
\text { idade, } \\
2000\end{array}$ & $\begin{array}{c}\text { População de } \\
25 \text { anos } \\
\text { ou mais de } \\
\text { idade, } 2000\end{array}$ \\
\hline $\begin{array}{l}\text { Belo Horizonte } \\
\text { (MG) }\end{array}$ & 35498 & 107100 & 190048 & 125257 & 241274 & 87333 & 1241141 \\
\hline Betim (MG) & 6396 & 19771 & 32139 & 19641 & 33187 & 12089 & 144533 \\
\hline Brumadinho (MG) & 499 & 1432 & 2490 & 1483 & 2499 & 964 & 14254 \\
\hline Caeté (MG) & 622 & 1838 & 3478 & 2226 & 3817 & 1316 & 19229 \\
\hline Confins (MG) & 91 & 285 & 430 & 262 & 521 & 169 & 2512 \\
\hline
\end{tabular}




\begin{tabular}{|c|c|c|c|c|c|c|c|}
\hline Contagem (MG) & 9635 & 29475 & 50071 & 31893 & 59755 & 21350 & 277992 \\
\hline Esmeraldas (MG) & 1122 & 3411 & 4872 & 2666 & 4494 & 1679 & 22365 \\
\hline Ibirité (MG) & 3134 & 9227 & 13843 & 8244 & 14539 & 5296 & 61215 \\
\hline Igarapé (MG) & 544 & 1560 & 2689 & 1585 & 2502 & 933 & 11871 \\
\hline Juatuba (MG) & 343 & 1068 & 1754 & 1034 & 1660 & 620 & 7826 \\
\hline Lagoa Santa (MG) & 708 & 2111 & 3723 & 2311 & 3802 & 1326 & 19598 \\
\hline $\begin{array}{l}\text { Mateus Leme } \\
(\mathrm{MG})\end{array}$ & 455 & 1398 & 2463 & 1527 & 2477 & 900 & 12138 \\
\hline $\begin{array}{l}\text { Mário Campos } \\
\text { (MG) }\end{array}$ & 219 & 677 & 1160 & 631 & 1100 & 378 & 4942 \\
\hline Nova Lima (MG) & 1067 & 3170 & 5924 & 3783 & 6914 & 2522 & 34462 \\
\hline $\begin{array}{l}\text { Pedro Leopoldo } \\
(\mathrm{MG})\end{array}$ & 926 & 2933 & 5252 & 3305 & 5544 & 1873 & 28193 \\
\hline Raposos (MG) & 248 & 712 & 1414 & 893 & 1614 & 583 & 7138 \\
\hline $\begin{array}{l}\text { Ribeirão das } \\
\text { Neves (MG) }\end{array}$ & 5544 & 16617 & 25715 & 15686 & 28307 & 10137 & 113719 \\
\hline Rio Acima (MG) & 159 & 425 & 815 & 479 & 792 & 300 & 3810 \\
\hline Sabará (MG) & 2369 & 6926 & 11219 & 7072 & 12604 & 4534 & 57118 \\
\hline Santa Luzia (MG) & 4010 & 11618 & 18776 & 11416 & 20611 & 7406 & 88954 \\
\hline Sarzedo (MG) & 361 & 1115 & 1841 & 1141 & 1871 & 684 & 8119 \\
\hline $\begin{array}{l}\text { São Joaquim de } \\
\text { Bicas (MG) }\end{array}$ & 450 & 1226 & 1899 & 1184 & 1988 & 703 & 8370 \\
\hline $\begin{array}{l}\text { São José da Lapa } \\
(\mathrm{MG})\end{array}$ & 346 & 922 & 1531 & 883 & 1526 & 548 & 7437 \\
\hline Vespasiano (MG) & 1756 & 5101 & 7641 & 4907 & 8588 & 3102 & 35879 \\
\hline
\end{tabular}

Fonte: Atlas do Desenvolvimento Humano no Brasil

Diante dos dados acima expostos, infere-se que a tanto a população criminosa quanto a não-criminosa são significativamente jovens, revelando assim, que a grande maioria dos criminosos possui idade até os 35 anos de idade. Isso porque, conforme destacado por Adorno e Bordini (1989) essa é a faixa etária mais susceptível de elaboração de uma identidade e carreira criminosas através do contato com agências de controle e de repressão, sobretudo porque a primeira detenção é, normalmente, o início de uma freqüentemente longa série de novos contatos. 
Escolaridade: supõe-se comumente que o nível educacional dos presos seja baixo. Esta suposição está fundada no seguinte argumento. Supõe-se que o processo de socialização do indivíduo, a inculcação de valores e normas coletivas dá-se mais na escola do que na família. Baseando na assertiva de que a escolarização é pressuposto da integração dos indivíduos no convívio social, lícito é inferir que os não-escolarizados serão as pessoas mais inaptas ao convívio social e, portanto, aqueles mais propensos a adotar comportamentos desviantes (Quadro 8).

Quadro 8 - Grau de escolaridade da população carcerária da RMBH

\begin{tabular}{|c|c|c|c|c|c|c|c|c|c|}
\hline Estabelecimentos da RMBH & 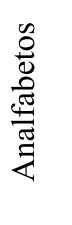 & 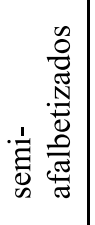 & 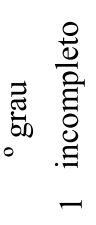 & 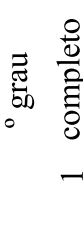 & 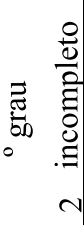 & 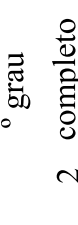 & 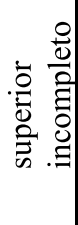 & 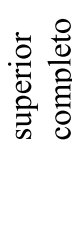 & 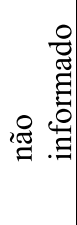 \\
\hline Casa de Albergado Presidente João Pessoa & 2 & 5 & 39 & 6 & 10 & 6 & 0 & 1 & 1 \\
\hline Casa de Detenção Antônio Dutra Ladeira & 33 & 122 & 531 & 92 & 53 & 28 & 2 & 0 & 112 \\
\hline Centro de Apoio Geral São Francisco & 4 & 10 & 8 & 0 & 0 & 0 & 0 & 0 & 2 \\
\hline Complexo Penitenciário Feminino Estevão Pinto & 12 & 31 & 65 & 10 & 9 & 5 & 0 & 3 & 7 \\
\hline Penitenciária José Abranches Gonçalves & 0 & 9 & 36 & 6 & 8 & 1 & 0 & 0 & 1 \\
\hline Penitenciária José Maria de Alkimin & 41 & 131 & 426 & 62 & 18 & 13 & 0 & 3 & 82 \\
\hline Penitenciária Nelson Hungria & 42 & 89 & 593 & 104 & 40 & 29 & 7 & 10 & 40 \\
\hline Penitenciária Prof. Jason Soares Albergaria & 16 & 59 & 176 & 22 & 12 & 5 & 1 & 0 & 45 \\
\hline TOTAL RMBH & 150 & 456 & 1874 & 302 & 150 & 87 & 10 & 17 & 290 \\
\hline$\% \mathrm{RMBH}$ & 4,50 & 13,67 & 56,18 & 9,05 & 4,50 & 2,61 & 0,30 & 0,51 & 8,69 \\
\hline$\%$ RMBH em relação ao total de presos & 2,00 & 6,07 & 24,94 & 4,02 & 2,00 & 1,16 & 0,13 & 0,23 & 3,86 \\
\hline
\end{tabular}

Fonte: Secretaria de Estado de Defesa Social - Janeiro de 2005

O Quadro 8 demonstra que o grau de escolaridade dos presos é excessivamente baixo, ou seja, 74,34\% dos detentos da RMBH não possuem sequer o primeiro grau. No entanto, é importante ressaltar que a baixa escolaridade não é um privilégio da população criminosa ou da população carcerários, atingindo outros grupos que se encontram inseridos de modo precário nas diversas instituições mantenedoras dos direitos políticos, civis e sociais (quadro 9). 
Quadro 9 - Percentual de Pessoas por Nível de Ensino, em 2000, na Região Metropolitana de Belo Horizonte (Minas Gerais)

\begin{tabular}{|c|c|c|c|c|c|}
\hline Município & $\begin{array}{l}\text { Taxa bruta de } \\
\text { freqüência ao } \\
\text { fundamental, } \\
2000\end{array}$ & $\begin{array}{c}\text { Taxa bruta de } \\
\text { freqüência ao } \\
\text { ensino médio, } \\
2000\end{array}$ & $\begin{array}{c}\text { Taxa bruta de } \\
\text { freqüêencia } \\
\text { ao superior, } \\
2000\end{array}$ & $\begin{array}{c}\% 18 \text { a } 22 \\
\text { anos que } \\
\text { freqüentam } \\
\text { curso } \\
\text { superior, } \\
2000\end{array}$ & $\begin{array}{c}\% 18 \text { a } 22 \text { anos } \\
\text { com } \\
\text { acesso ao } \\
\text { curso } \\
\text { superior, } \\
2000\end{array}$ \\
\hline Belo Horizonte (MG) & 123,39 & 108,91 & 33,91 & 15,15 & 15,26 \\
\hline Betim (MG) & 129,58 & 89,18 & 8,16 & 2,97 & 3 \\
\hline Brumadinho (MG) & 126,79 & 94,1 & 10,48 & 1,6 & 1,6 \\
\hline Caeté (MG) & 124,35 & 102,15 & 9,2 & 3 & 3 \\
\hline Confins (MG) & 125,31 & 109,74 & 4,01 & 0,66 & 0,69 \\
\hline Contagem (MG) & 123,3 & 108,52 & 13,22 & 4,98 & 5 \\
\hline Esmeraldas (MG) & 120,19 & 49,69 & 4,31 & 2,02 & 2,02 \\
\hline Ibirité (MG) & 121,88 & 76,41 & 1,62 & 0,68 & 0,68 \\
\hline Igarapé (MG) & 124,43 & 83,48 & 6,05 & 3,2 & 3,2 \\
\hline Juatuba (MG) & 121,78 & 103,13 & 7,04 & 1,9 & 1,91 \\
\hline Lagoa Santa (MG) & 123 & 114,62 & 8,39 & 2,85 & 2,85 \\
\hline Mateus Leme (MG) & 121,2 & 77,12 & 7,79 & 4,04 & 4,04 \\
\hline Mário Campos (MG) & 117,56 & 81,04 & 1,99 & 0,01 & 0,02 \\
\hline Nova Lima (MG) & 133,35 & 116,61 & 17,71 & 7,69 & 7,79 \\
\hline Pedro Leopoldo (MG) & 125,53 & 93,55 & 16,45 & 3,69 & 3,69 \\
\hline Raposos (MG) & 117,89 & 117,8 & 4,73 & 0,71 & 0,71 \\
\hline Ribeirão das Neves (MG) & 122,51 & 83,92 & 2,15 & 0,44 & 0,44 \\
\hline Rio Acima (MG) & 116,29 & 60,58 & 3,47 & 0,34 & 0,35 \\
\hline Sabará (MG) & 124,92 & 102,07 & 9,23 & 3,09 & 3,09 \\
\hline Santa Luzia (MG) & 121,66 & 90,92 & 4,66 & 1,42 & 1,42 \\
\hline Sarzedo (MG) & 119,06 & 73,44 & 2,48 & 0,55 & 0,55 \\
\hline São Joaquim de Bicas (MG) & 129,85 & 69,78 & 4,62 & 1,16 & 1,16 \\
\hline São José da Lapa (MG) & 105,75 & 101,14 & 5,14 & 0,52 & 0,52 \\
\hline Vespasiano (MG) & 122,87 & 89,85 & 6,52 & 2,47 & 2,47 \\
\hline
\end{tabular}

Fonte: Atlas do Desenvolvimento Humano no Brasil

Destarte, o que se verifica é que tanto na população não-criminosa quanto na população encarcerada, as pessoas possuem, majoritariamente, ensino fundamental incompleto. Assim, a comparação entre os graus obtidos pelos presos e pela população em geral é mais intrincada. Pode-se apenas fazer alguns comentários sobre os dados do IDH e sobre a informação coletada nas prisões. No que se denomina ensino fundamental 
incompleto, a população carcerária encontra-se majoritariamente neste patamar, conforme acima aduzido, no mesmo sentido se percebe do resto da população em geral.

Logo, não é na falta de instrução básica que se deve buscar o perfil diferencial dos presos. Nesses termos, a peculiaridade da população encarcerada situa-se na idade de sua prisão, a qual pode significar a interrupção do processo de escolarização com demarcadas conseqüências no adestramento necessário e mesmo mínimas à competição no mercado de trabalho (Adorno e Bordini,1989).

Ocupação: idade, local de nascimento, escolaridade, têm visível relação com o ingresso na força de trabalho e com as oportunidades ocupacionais. Sabendo-se que os estabelecimentos penais possuem uma população jovem (a maior parte com menos de 30 anos de idade) e que alguns foram muito cedo para a cadeia, é possível que os presos não sejam originariamente "vagabundos".

Para se analisar essa questão optou-se pela criação das seguintes categorias: ocupação que requer curso superior; ocupação que não requer curso superior; aposentado; sem profissão e não informado (Quadro 10). Ademais, os dados em questão levam em conta a ocupação principal do indivíduo, o que significa aquele ramo de atividade em que ele permaneceu por mais tempo, ainda que tenha mudado de função ou local de trabalho. Nesse sentido, o objetivo dessa categoria acabou por cingir-se à verificação do prestígio que a posição ocupada pelo indivíduo possui socialmente.

Quadro 10 - Natureza das atividades exercidas pelos sentenciados da RMBH antes do encarceramento

\begin{tabular}{|l|l|l|r|r|r|}
\hline Estabelecimentos da RMBH & $\begin{array}{l}\text { Ocupação } \\
\text { que requer } \\
\text { curso } \\
\text { superior }\end{array}$ & $\begin{array}{l}\text { Ocupação } \\
\text { que não } \\
\text { requer curso } \\
\text { superior }\end{array}$ & Aposentado & $\begin{array}{l}\text { Sem } \\
\text { profissão }\end{array}$ & $\begin{array}{l}\text { Não } \\
\text { informado }\end{array}$ \\
\hline Casa de Albergado Presidente João Pessoa & 0 & 62 & 0 & 4 & 3 \\
\hline Casa de Detenção Antônio Dutra Ladeira & 5 & 721 & 5 & 50 & 133 \\
\hline Centro de Apoio Geral São Francisco & 0 & 19 & 1 & 2 & 2 \\
\hline $\begin{array}{l}\text { Complexo Penitenciário Feminino Estevão } \\
\text { Pinto }\end{array}$ & 5 & 105 & 2 & 21 & 8 \\
\hline Penitenciária José Abranches Gonçalves & 0 & 53 & 0 & 4 & 4 \\
\hline Penitenciária José Maria de Alkimin & 7 & 628 & 1 & 58 & 82 \\
\hline
\end{tabular}




\begin{tabular}{|l|r|r|r|r|r|}
\hline Penitenciária Nelson Hungria & 18 & 864 & 1 & 31 & 38 \\
\hline Penitenciária Prof. Jason Soares Albergaria & 2 & 407 & 1 & 15 & 27 \\
\hline TOTAL RMBH & 37 & 2859 & 11 & 185 & 297 \\
\hline \% RMBH & 1,09 & 84,36 & 0,32 & 5,46 & 8,76 \\
\hline \% RMBH em relação ao total de presos & 0,50 & 38,42 & 0,15 & 2,49 & 3,99 \\
\hline
\end{tabular}

Fonte: Secretaria de Estado de Defesa Social - Janeiro de 2005

Em um segundo momento, optou — se por desagregar as ocupações que não requerem curso superior. Com isso, contatou-se que $19,01 \%$ da população encarcerada da RMBH estava ocupada, antes da prisão, no setor da construção civil. Este ramo está marcado pela instabilidade do emprego, sujeito às oscilações do mercado de construção civil. Em seguida, aparecem os trabalhadores do setor Terciário (comércio e prestação de serviços) perfazendo um total de $17 \%$ da população encarcerada. Referido ramo configurase, de modo geral, como um trabalho exercido nas ruas da cidade, tais como office boy, entregadores de supermercado, ambulantes, etc., sugerindo efemeridade e baixa remuneração e qualificação. Em terceiro lugar, verifica-se a ocorrência do setor Secundário (Indústrias e Transformações) agregando $7,08 \%$ dos encarcerados. É um ramo mais condicionado pela idade em que se entra no mercado de trabalho e pela maior proximidade com os grandes centros urbanos. Por fim, cumpre ressaltar que $18,47 \%$ dos encarcerados pertencem à categoria outras profissões o que denota a dificuldade em se separar as diversas profissões por eles ocupadas.

Portanto, é possível afirmar que os encarcerados provêm de experiências laborais pouco qualificadas e mal remuneradas, o que de forma geral, ocorre com a população nãocriminosa. Tendo em vista a má-distribuição de renda e o elevado índice de desemprego, mormente entre classes sociais baixas, infere-se que o mercado de trabalho formal está adstrito a uma pequena parte da população, na maioria das vezes, detentora de maior qualificação profissional. Os dados da Pesquisa de Emprego e Desemprego elaborada pela Fundação João Pinheiro em 2003 comprovam tal assertiva.

Em 2003, os níveis de escolaridade mais afetados pela intensificação do desemprego foram os de menor instrução, sendo o aumento de 15,4\% para as pessoas que possuíam ensino fundamental incompleto, $12,8 \%$ para aquelas com ensino fundamental completo e ensino médio incompleto, e 12,3\% para os analfabetos. A taxa de desemprego decresceu apenas para as pessoas que já contavam com o ensino superior completo (12,9\%), o que 
contribuiu para que essa taxa de desemprego continuasse sendo a menor entre os níveis de escolaridade (5,4\%) (Pesquisa de Emprego e Desemprego da FJP, 2003).

Daí porque é possível concluir que a condição de trabalhador de baixa qualificação não orienta necessariamente a opção para uma carreira criminosa, o que, por sua vez, reafirma a falácia tanto da oposição entre identidade trabalhadora e identidade delinqüente quanto a falácia do criminoso "de nascença", renitente ao trabalho, ocioso e vadio por natureza. É preciso atentar que a criminalidade é um fenômeno distribuído por toda a estrutura de classes sociais. Portanto, os trabalhadores não qualificados, mais vulneráveis aos efeitos intimidativos da atividade policial, parecem cometer delitos em proporções muito maiores que os demais (Adorno e Bordini, 1989).

Assim, quaisquer políticas públicas que pretendam ressocializar o indivíduocriminoso exclusivamente via escolarização e profissionalização com oferta de cursos supletivos e prévestibulares ou cursos profissionalizantes serão insuficientes uma vez que tais perfis pertencem tanto à população criminosa quanto à população não-criminosa, não sendo, portanto, causas determinantes do comportamento desviante, ou seja, não é a baixa escolaridade e profissionalização que causam, por si só, o crime. Ou seja, não se deve imputar, necessariamente, à marginalidade social a causa de engajamentos preferenciais na criminalidade; ficando esta proposição ao mero domínio da crença.

O grau de escolaridade e a ocupação principal dos apenados, pelos dados empíricos aqui trazidos, não são muito discrepantes da população em geral. Dessa forma, num primeiro momento, políticas públicas destinadas a reverter esse quadro, teriam que se aplicar à população como um todo e não somente aos encarcerados. Todavia, fato é que o convívio escolar e as atividades laborais constituem meios contundentes de inserção social, o que demonstra a coerência de políticas públicas que promovam o aumento da escolaridade e a inserção no mercado de trabalho como meio de ressocialização do indivíduo delinqüente, ainda que não de forma determinante.

6 - Das espécies de crimes mais recorrentes entre os encarcerados da Região Metropolitana de Belo Horizonte 
Nunca a questão da violência e da criminalidade suscitou tantos debates públicos quanto atualmente. Talvez, a magnitude da insegurança pública tenha dado ensejo a essas reações coletivas. As crescentes demandas por segurança privada como: circuitos internos de $\mathrm{TV}$, vigias, alarmes, trancas, etc., corroboram a insegurança generalizada a que atingiram os grandes centros urbanos. Ora, dados estatísticos comprovam que o número de ocorrências registradas de crimes violentos tem aumentado e que certos setores de crimes, como os contra o patrimônio e o tráfico de entorpecentes, contam com organizações de molde empresarial.

Tal fenômeno, encontra respaldo na magnitude dos crimes contra o patrimônio, empiricamente verificadas, consoante consta do quadro 6. Neste se verifica que 27,66 \% dos crimes configuram o crime de roubo, sendo que, foram decotadas todas as ocorrências do artigo $157 \S 3^{\circ}$ que são o roubo de que resulta lesão corporal grave ou morte (latrocínio), ficando este no percentual de 3,90\% dos crimes cometidos. O segundo crime mais cometido pelos sentenciados da RMBH é o furto, cuja ocorrência está no percentual de 19,41\%, seguido do tráfico de entorpecentes que se encontra no patamar de 12,02\%. Disso se depreende o seguinte: os crimes contra o patrimônio são a causa do maior número de encarceramentos na Região Metropolitana de Belo Horizonte.

Quadro 8 - Crimes pelo qual os sentenciados da RMBH estão cumprindo pena privativa de liberdade

\begin{tabular}{|l|r|r|}
\hline Categoria criminosa & No absoluto & Percentual \\
\hline Sem registro de processos & 76 & 1,228 \\
\hline Ameaça & 20 & 0,323 \\
\hline Contravenção penal & 30 & 0,485 \\
\hline Crimes contra a Administração Pública & 70 & 1,131 \\
\hline Crimes contra a liberdade sexual & 269 & 4,346 \\
\hline Crimes previstos na Lei de Armas & 238 & 3,846 \\
\hline Dano qualificado & 20 & 0,323 \\
\hline Destruição, subtração ou ocultação de cadáver & 42 & 0,679 \\
\hline Estelionato & 92 & 1,487 \\
\hline
\end{tabular}




\begin{tabular}{|c|c|c|}
\hline Extorsão & 48 & 0,776 \\
\hline Furto & 1201 & 19,405 \\
\hline Homicídio culposo & 14 & 0,226 \\
\hline Homicídio qualificado & 497 & 8,030 \\
\hline Homicídio simples & 84 & 1,357 \\
\hline Latrocínio & 245 & 3,959 \\
\hline Lesão corporal & 95 & 1,535 \\
\hline Outros & 91 & 1,470 \\
\hline Outros contra a fé pública & 100 & 1,616 \\
\hline Outros contra a pessoa & 44 & 0,711 \\
\hline Outros contra o patrimônio & 3 & 0,048 \\
\hline Quadrilha ou bando & 59 & 0,953 \\
\hline Rapto & 68 & 1,099 \\
\hline Receptação & 53 & 0,856 \\
\hline Roubo & 1712 & 27,662 \\
\hline Tráfico de entorpecentes & 744 & 12,021 \\
\hline Uso de entorpecentes & 274 & 4,427 \\
\hline TOTAL & 6189 & 100 \\
\hline
\end{tabular}

Fonte: Secretaria de Estado de Defesa Social - Janeiro de 2005

Os dados demonstram que a maioria dos crimes cometidos pelos sentenciados da RMBH tem como finalidade a obtenção do lucro rápido, algo que muitas vezes não é passível de ser alcançado, por esses indivíduos, por meio do trabalho livre. Nesses termos, a criminalidade poderia se apresentar como um padrão de conduta legítimo para esses jovens com baixa escolaridade e inseridos de forma precária no mercado de trabalho.

A assertiva acima encontra respaldo na pesquisa de campo executada na Penitenciária José Maria Alkimin, com os detentos do regime semi-aberto, em que 73,34 \% dos 
entrevistados cometeram os crimes de furto, roubo e/ou tráfico de drogas, sendo que destes, $59,09 \%$ atribuíram às dificuldades financeiras/falta de emprego, a causa principal do cometimento do ilícito. Ora, dos dados acima expostos, verifica-se que dos crimes cometidos contra o patrimônio, quase $60 \%$ são motivados pelas dificuldades financeiras em sobreviver e auferir renda, estando os demais motivados, principalmente, pela influência de amigos, conforme anteriormente assinalado. Estes dados corroboram a tese de Merton (1968) que confere à busca pelos padrões de sucesso pessoal, alcançadas pelo dinheiro, como fim a ser perseguido pelos indivíduos, caso em que, aqueles que não dispõem de meios institucionalizados para tal, socialmente aceitos, adotam as vias ilegítimas, para se alcançar referidos fins.

Assim asseveraram dois dos entrevistados quando foram interrogados acerca dos motivos que o levaram a cometer o crime: "Eu trabalhava muito, mas meu salário era muito baixo. Não havia necessidade enorme para o crime, mas eu queria as coisas boas: roupa, viagem, carro e não tinha como. Mas o dinheiro fácil do crime falou mais alto (...)" (Entrevistado 13). Assim respondeu outro entrevistado à mesma pergunta: "Devido à facilidade de obter drogas, devido à necessidade de sobrevivência, dificuldade que a vida oferece para nós de arranjar outros tipo de recurso que são os certos" (Entrevistado 15). O que se pode inferir das passagens acima é que na primeira resposta atesta-se a busca pelos padrões de sucesso pessoal mencionadas por Merton (1968) (padrões culturais a serem obtidos), enquanto que na segunda resposta, atesta-se as dificuldades que estes indivíduos têm de alcançar os fins almejados pelas vias institucionalizadas. Essa disfunção entre a estrutura social e cultural é a gênese do comportamento desviante.

Por derradeiro, cumpre ressaltar que a precariedade do emprego que ocupava os indivíduos antes de sua prisão (condições insalubres de trabalho, baixa remuneração, instabilidade, etc.) propicia a adoção de comportamentos desviantes, o que denota que não é a simples ausência de emprego que estimula o ato criminoso, mas a precariedade deste também. Tanto assim que, 50\% dos entrevistados estavam empregados quando do cometimento do ato ilícito. A questão precípua cinge-se ao tipo de trabalho exercido pela imensa maioria dos encarcerados: os trabalhos configuram bicos, estando os indivíduos desprovidos de quaisquer garantias trabalhistas ou permanência no emprego. Portanto, não basta conceder-lhes uma oportunidade de trabalho, essencial se faz propiciar-lhes cursos 
profissionalizantes, de forma a produzir mão de obra qualificada e especializada. Tais resultados apontam no mesmo sentido dos levantados por Vinícius Caldeira Brant em sua obra " O trabalho encarcerado" em 1994.

Portanto, os presos da Região Metropolitana de Belo Horizonte têm o seguinte perfil: são indivíduos jovens, pouco escolarizados e malgrado possuírem experiências anteriores de trabalho, estas configuram trabalhos desqualificados, mal remunerados e instáveis, desprovidos de quaisquer garantias trabalhistas e entre os fatores por eles apontados como motivadores para o cometimento do crime, ressaltam-se os seguintes: desemprego, com conseqüente dificuldade de inserção no mercado formal de trabalho e influência de amigos. Isso significa que, qualquer política pública de ressocialização deve, necessariamente, atentar para tais fatores: a disponibilidade de cursos profissionalizantes, bem como o encaminhamento para o mercado formal de trabalho e a escolaridade e apoio à família, como forma de endossar o processo de inculcação dos valores éticos e morais da consciência coletiva, com o desiderato de minimizar as influências do meio criminoso circundante que porventura possa existir.

\section{7 - Considerações Finais}

Durante vários anos o indivíduo condenado a uma pena privativa de liberdade esteve relegado a um plano inferior, vítima do descaso e da falta de compromisso das autoridades encarregadas de cuidar do problema da criminalidade, do tratamento e da recuperação do preso. Assim, o condenado era submetido a um tratamento hostil, desprovido de qualquer preocupação com sua recuperação.

A partir do século XIX a pessoa do delinqüente passou a ser objeto de estudo científico e a pena privativa de liberdade passou a ser vista como solução do problema da criminalidade. De certa forma, ela representava uma evolução dos métodos empregados para corrigir o homem que se desviou do caminho do bem. Este tratamento penitenciário é composto por um conjunto de medidas médicas, psicológicas, pedagógicas, sociais e educativas, com o objetivo de remodelar a personalidade do condenado, facilitar a sua readaptação social e, consequentemente, prevenir a reincidência. A administração penitenciária deve buscar incutir na cabeça do condenado valores morais, éticos e religiosos, 
despertando-lhe o sentimento de autoconfiança, a auto-estima, o respeito por ele mesmo, pelo "outro" e pela sociedade. Para o êxito do tratamento, é necessário que o estabelecimento tenha uma equipe de profissionais altamente qualificada e com experiência na área criminológica para acompanhar e orientar o condenado no sentido de que ele aceite o tratamento, sem manipulação ou ameaças e conscientemente mude o seu comportamento. Cumpre salientar a imprescindibilidade de uma infra-estrutura adequada ao propósito da Lei de Execução Penal.

Todavia, o que se verifica nos estabelecimentos penitenciários é exatamente o

contrário. Esta pena imposta apenas para castigar, punir, retribuir, tal como está sendo executada pelos estabelecimentos penitenciários atualmente, só veio a agravar o problema, pois o condenado não é submetido a um tratamento penitenciário efetivo que possa modificar a sua personalidade, remodelando-a, visando a sua reintegração na sociedade e evitando a reincidência. Os dados empíricos colacionados ao presente estudo denotam que a ausência de ensino escolar, ou a precariedade deste (forma indispensável de inculcação dos valores éticos e morais da consciência coletiva), bem como a execução de um trabalho como mera reapropriação do tempo suspendido pela condenação, destituído de um caráter "educador", com efetiva formação profissional, apontam para uma execução penal desprovida de qualquer preocupação para com a recuperação do sentenciado, tornando imprescindível políticas públicas que atuem nesse sentido após sua liberação.

Nesse sentido, resta irrefragável a importância de um projeto de reinserção social dos egressos do sistema penitenciário, pautado por ações de cunho profissional, escolar, sóciofamiliar e psicossocial, estendido ao ex-sentenciado e seus familiares. Todavia, nunca políticas de reinserção social para egressos do sistema penitenciário suprirão os danos morais causados aos indivíduos no que se refere ao tratamento desumano a que são submetidos no interior da unidade prisional, fazendo-se premente a reciclagem do pessoal penitenciário, com preparação técnica e formação humanística, a fim de que estejam imbuídos de sua alta missão social: a mortificação do criminoso e o resgate do homem.

\section{8 - Referências}


ADORNO, Sérgio e BORDINI, Eliana Blumer T. 1989. "Reincidência e reincidentes penitenciários em São Paulo”, 1974-1985. In: Dados. Revista de Ciências Sociais. Rio de Janeiro. $\mathrm{n}^{\circ}$ 9, vol. 3, p. 70-94.

ANGHER, Anne Joyce(org.)., 2002. Código Penal, Código de Processo Penal, Constituição Federal. 2.ed. São Paulo: Rideel, 2002.

BRASIL. Lei n. ${ }^{\circ}$ 7210, de 11 de julho de 1984. Institui a Lei de Execução Penal. Diário

Oficial [ da] República Federativa do Brasil, Brasília, 11 jul. 1984. [ Seção, p.] BRANT, Vinicius Caldeira. 1994. O trabalho encarcerado. Rio de Janeiro: Forense.

COHEN, Albert K. 1968. Transgressão e controle. São Paulo: Pioneira.

COSTA, Alexandre Marino. 1999. O trabalho prisional e a reintegração social do detento. Florianópolis: Insular, 1999

DIAS, Jorge de Figueiredo; ANDRADE, Manuel da Costa. 1997. Criminologia: O homem delinqüente e a sociedade criminógena. 2. Ed. São Paulo: Coimbra Editora Ltda. DURKHEIM, Émile. 1999. As regras do método sociológico. 2. ed . São Paulo: Martins Fontes.

DURKHEIM, Émile. 1999. Da divisão do trabalho social. 2. ed. São Paulo: Martins Fontes. FOUCAULT, Michel. 2000. Vigiar e punir. 23. ed. Petrópolis: Vozes. 
FREITAS, Wagner Cinelli de Paula. 2002. Espaço Urbano e Criminalidade: lições da escola de Chicago. São Paulo: IBCCRIM.

GOFFMAN, Erving. 1999. Manicômios, prisões e conventos. 6. Ed. São Paulo:

Perspectiva.

LEMGRUBER, Julita. Controle da criminalidade: mitos e fatos. Encarte especial Think Tank.

MAGAlHÃES, Carlos A T. 1996. Crime, Sociologia e Políticas Públicas. Dissertação de mestrado, mimeo. UFMG. Belo Horizonte.

MERTON, Robert. 1978. Sociologia e estrutura. Lisboa: Perspectiva, 1978

MIRABETE, Júlio Fabrini. 2000.Execução penal: comentários à lei n. ${ }^{\circ}$ 7210/84. São Paulo: Atlas.

PERALVA, Angelina. 2000. Violência e democracia: o paradoxo brasileiro São Paulo: Paz e Terra.

PINTO, Alessandro Nepomoceno; SÁ, Alvino Augusto; LEAL, Maria Neuma Castelo de Souza. Apostila de Criminologia. 2003. Ministério da Justiça. DEPEN. Brasília.

PRADO, Luís Regis. 2002.1v. Curso de Direito Penal Brasileiro. 3.ed. São Paulo: Editora Revista dos Tribunais.

RAMALHO, José Ricardo. 2002. O mundo do crime: A ordem pelo avesso. São Paulo: IBCCRIM.

SAPORI, Luís Flávio; WANDERLEY, Cláudio Burian. "A relação entre desemprego e violência na sociedade brasileira: entre o mito e a realidade". 2001. In: NELO, Paulo de Mesquita; VIEIRA, Oscar Vilhena; LIMA, Flávio Augusto Fontes de; TISCÓRNIA, Sofía. A violência do cotidiano. São Paulo: Fundação Konrad Adenauer. 